\title{
PERFORMA AYAM KAMPUNG SUPER YANG DIBERI RANSUM DENGAN LEVEL PROTEIN DAN ENZIM BERBEDA
}

\section{Performance of Kampung Super Chicken Given Ration With Different Protein and Enzymes Levels}

\author{
Noferdiman'1, Sestilawarti', M. Fiqliah'1, dan A. Ilda ${ }^{1}$ \\ ${ }^{1}$ Program Studi Peternakan Fakultas Peternakan Universitas Jambi \\ Email: noferdiman@unja.ac.id.
}

\begin{abstract}
ABSTRAK
Penelitian ini bertujuan untuk mengetahui performa ayam kampung super yang diberi ransum dengan penggunaan level protein dan enzim berbeda. Rancangan yang digunakan dalam penelitian ini yaitu Rancangan Acak Lengkap (RAL) pola faktorial 3 x 2 terdiri yang dari 4 ulangan. Perlakuan yang diberikan terdiri atas faktor pertama yaitu faktor protein dengan level P1: 16\%, P2: 18\%, dan P3: 20\%; sedangkan faktor kedua yaitu enzim dengan level E0: 0,00\% dan E1: 0,10\%. Peubah yang diamati adalah konsumsi ransum, pertambahan bobot badan, konversi ransum, bobot potong, bobot karkas mutlak dan bobot karkas relatif. Data dianalisis menggunakan analisis ragam (ANOVA) jika berpengaruh nyata dilanjutkan dengan uji jarak berganda Duncan. Hasil penelitian menunjukan bahwa pengaruh penggunaan level protein dan enzim dalam ransum menunjukkan interaksi yang tidak nyata $(\mathrm{P}>0,05)$ terhadap konsumsi dan konversi ransum, bobot potong, bobot karkas mutlak dan bobot karkas relatif, sedangkan pada masing-masing penggunaan level protein dan enzim dalam ransum berpengaruh nyata $(\mathrm{P}<0,05)$ terhadap pertambahan bobot badan, bobot potong, bobot karkas mutlak dan bobot karkas relatif. Kesimpulan penelitian ini adalah penggunaan level protein $20 \%$ dan enzim $0,10 \%$ dapat meningkatkan pertambahan bobot badan dan bobot karkas ayam kampung super.
\end{abstract}

Kata kunci: Ayam Kampung Super, Bobot Karkas, Enzim, Pertambahan Bobot Badan, Protein

\begin{abstract}
This study was aimed to determine the effect of different level of protein and enzymes on the performance of kampung super chickens. The research was design based on Completely Randomized Design (CRD) $3 \times 2$ factorial patterns; each treatment consists of 4 replications. The treatments given consisted of the first factor were the protein level which T1: 16\%, T2: 18\% and T3: 20\%; the second factor were either level enzyme, E0: 0.00\% and E1: 0.10\%. The variables observed were feed consumption, feed conversion ratio, body weight gain, body weight, absolute and relative carcass weight. Data were analyzed by analysis of variance (ANOVA), if significantly different between treatments, continued with Duncan's multiple range tests. The results showed that the effect of dietary protein and enzyme levels had not significant interaction ( $P>0.05$ ) on feed consumption, feed conversion ratio, body weight, absolute and relative carcass weight, and had signifivant effect on $(P<0.05)$ on body weight gain, body weight, absolute relative carcass weight. The conclusion of this study was the use of protein levels of $20 \%$ and $0.10 \%$ enzyme respectively can increase body weight gain and carcass weight of kampung super chickens.
\end{abstract}

Keywords: Kampung Super Chicken, Carcass Weight, Enzyme, Body Weight Gain, Proteins

\section{PENDAHULUAN}

Peternakan unggas di Indonesia saat ini telah mengalami perkembangan yang sangat pesat, sejalan dengan meningkatnya kesadaran masyarakat akan pentingnya pemenuhan nilai gizi yang 
bersumber dari protein hewani, salah satunya berasal dari ternak ayam kampung super. Ayam kampung super merupakan ayam kampung hasil persilangan antara ayam bangkok sebagai pejantan dengan betina yang berasal dari ayam ras. Masa panen ternak ayam kampung super ini lebih singkat, sehingga akan memberikan banyak keuntungan yaitu risiko kematian yang kecil dan menghemat biaya pemeliharaan termasuk pakan. Menurut Udjianto (2018) ayam kampung ini juga dianggap mempunyai tekstur daging yang lebih kenyal dan kandungan nutrisi yang lebih tinggi.

Protein merupakan nutrisi yang sangat penting bagi tubuh ternak, penggunaan level protein dalam ransum ayam kampung super masih beragam, sehingga perlu dicari level protein yang tepat dan efisien untuk mencapai pertumbuhan maksimal. Bahan pakan sumber protein yang diberikan juga harus mengandung asam amino yang lengkap serta berimbang, sehingga penggunaan protein lebih efisien. Protein yang dikonsumsi akan disintesis menjadi asam amino dan digunakan untuk pembentukan daging, sehingga bobot badan akan bertambah. Pertambahan bobot badan sangat erat hubungannya dengan asupan protein ke dalam tubuh ternak.

Upaya peningkatan ayam kampung dalam menghasilkan daging yang berkualitas perlu diperhatikan pemeliharaan yang baik, serta penyediaan ransum yang berkualitas. Fitasari (2016) melaporkan pemeliharaan ayam lokal pedaging unggul umur 0-12 minggu dengan kandungan gizi ransum mengandung protein kasar 19\%-21\% dan energi metabolis 2.800-3000 kkal/kg pakan, memberikan pengaruh signifikan terhadap pertambahan bobot badan. Sedangkan Fitasari et al., (2017) melaporkan penggunaan kadar protein yang berbeda dalam pakan level 17\%, 18\%, 19\% dan 20\% tidak memberikan pengaruh terhadap konsumsi pakan, konsumsi air, pertambahan bobot badan, dan konversi pakan ayam kampung. Upaya untuk mencapai performa yang terbaik diperlukan ketersediaan protein dalam pakan. Penyediaan ini penting karena protein berperan penting terhadap pembentukan daging (Fanani et al., 2016). Menurut Nawawi and Nurrohmah (2015) ransum ayam kampung umur (0-12 minggu) membutuhkan protein sekitar 15-17\% dengan energi metabolis sebesar $2800 \mathrm{kkal} / \mathrm{kg}$. Penggunaan level protein dalam ransum ayam kampung super yang masih beragama ini, perlu dicari level protein yang tepat dan efisien untuk mencapai pertumbuhan maksimal.

Penyedian ransum yang berkualitas masih menemui banyak kendala sampai saat ini, upaya yang dapat dilakukan untuk meningkatkan pemanfaatan nutrien adalah dengan menggunakan penambahan enzim. Produk enzim yang digunakan adalah solagri 3 yang merupakan suplemen ternak berbentuk tepung dan dapat dicampurkan ke dalam ransum maupun air minum pada ternak, produk ini mengandung enzim-enzim bermutu dan vitamin untuk ternak seperti phytase, amilase, protease, xylanase dan ß-glucanase. Enzim selulase, protease dan xylanase merupakan enzim yang dominan didalam produk ini. Manfaat yang di harapkan yaitu meningkatkan penyerapan nutrisi pakan oleh ternak dan mampu dicerna didalam saluran pencernaan sehingga enzim yang ditambahkan ini dapat mengkonversi dalam bentuk daging. Tujuan dari penelitian ini untuk mengetahui pengaruh penggunaan level protein dan enzim serta interaksinya dalam ransum terhadap performa ayam kampung super.

\section{METODE}

Materi yang digunakan pada penelitian ini adalah DOC ayam kampung super sebanyak 240 ekor yang berasal dari Kharim Farm Kediri Jawa Timur, produk enzim dengan merek "Solagri 3" di produksi oleh Bangkit Solusi Angrido, Bandung, Jawa Barat. Beberapa bahan pakan yang terdiri dari jagung, tepung ikan, bungkil kedele, dedak, bungkil kelapa, premix dan minyak, desinfektan cair, dan larutan kapur. Peralatan yang digunakan pada penelitian ini adalah kandang ternak ayam kampung 
tipe koloni dengan ukuran $140 \mathrm{~cm}$ x $100 \mathrm{~cm}$ x $70 \mathrm{~cm}$, terpal, lampu pijar, tempat pakan, tempat air minum, liter yang terdiri serbuk gergaji, dan timbangan.

Tabel 1. Komposisi Bahan Pakan Penyusun Ransum Perlakuan

\begin{tabular}{lccc}
\hline \multirow{2}{*}{ Bahan pakan } & \multicolumn{3}{c}{ Perlakuan (\%) } \\
\cline { 2 - 4 } & P1 & P2 & P3 \\
\hline Jagung & 44 & 40,1 & 38,8 \\
Bungkil kedelai & 12,5 & 17,4 & 23,1 \\
Bungkil kelapa & 9 & 10,6 & 10,5 \\
Dedak & 21 & 16,8 & 14 \\
Tepung ikan & 6 & 7 & 7,2 \\
Premix & 5,5 & 5,1 & 3,4 \\
Minyak kelapa & 2 & 3 & 3 \\
\hline Jumlah & 100 & 100 & 100 \\
\hline
\end{tabular}

Kandang terlebih dahulu dibersihkan dan diberi larutan kapur, dengan cara melumuri seluruh permukaan kandang koloni menggunakan kuas sehingga seluruh kandang basah, selanjutnya biarkan kandang mengering, siapkan liter atau alas yang terdiri dari serbuk gergaji dan dialasi alas koran, kemudian masukkan tempat pakan dan minum yang disertai lampu pijar. Kandang diberi nomor atau kode masing-masing perlakuan, kemudian masukkan 240 ekor DOC ayam kampung kedalam 24 unit kandang dan setiap kandang berisi 10 ekor DOC ayam kampung.

Tabel 2. Kandungan zat makanan ransum perlakuan

\begin{tabular}{lccc}
\hline \multirow{2}{*}{ Zat makanan } & \multicolumn{3}{c}{ Perlakuan (\%) } \\
\cline { 2 - 4 } & P1 & P2 & P3 \\
\hline Bahan Kering & 79,91 & 79,45 & 80,93 \\
Protein Kasar & 16,10 & 18,04 & 20,01 \\
Lemak Kasar & 5,05 & 4,63 & 4,27 \\
Serat Kasar & 4,7 & 4,48 & 4,14 \\
Kalsium & 0,55 & 0,57 & 0,49 \\
Fosfor & 0,74 & 0,74 & 0,71 \\
Metionin & 0,51 & 0,63 & 0,78 \\
Lisin & 0,95 & 0,81 & 0,73 \\
Energi Metabolis (kkal/kg) & 2813,03 & 2802,82 & 2805,44 \\
\hline
\end{tabular}

Ransum yang digunakan terdiri dari jagung, tepung ikan, bungkil kedelei, dedak, bungkil kelapa, premix, dan minyak (yang disusun berdasarkan 3 level protein yaitu 16\%, 18\% dan 20\%) serta enzim, ransum disusun sesuai dengan kebutuhan zat makanan ayam kampung. Masing-masing perlakuan ransum yang telah disusun, dianalisis proksimat untuk diketahui kandungan zat makanan ransum dari masing-maing perlakuan. Kandungan zat makanan ransum perlakuan disajikan pada Tabel 2.

Penelitian Rancangan Acak Lengkap (RAL) pola faktorial 3 x 2 terdiri dari 4 ulangan. Faktor pertama adalah penggunaan 3 level protein (16\%, 18\%, dan 20\%) dan faktor kedua adalah penggunaan enzim yaitu ransum tanpa enzim $(0,00 \%)$ dan ransum menggunakan enzim $(0,10 \%)$. Adapun uraian perlakuan yang diberikan disajikan pada Tabel 3. Peubah performa ayam kampung super yang diukur adalah : konsumsi ransum (g/ekor), pertambahan bobot badan (g/ekor), konversi ransum, bobot potong (g/ekor), bobot karkas mutlak (g/ekor), dan bobot karkas relatif (\%). 
Tabel 3. Kombinasi perlakuan level protein dan enzim

\begin{tabular}{cccc}
\hline \multirow{2}{*}{ Perlakuan } & \multicolumn{2}{c}{ (E) Enzim (\%) } \\
\cline { 2 - 4 } & & 0,00 & 0,10 \\
\hline \multirow{3}{*}{ (P) Level Protein (\%) } & 16 & P1E0 & P1E1 \\
& 18 & P2E0 & P2E1 \\
& 20 & P3E0 & P3E1 \\
\hline
\end{tabular}

Keterangan:

- P1E0 : ransum dengan level protein $16 \%$ tanpa penambahan enzim $0,00 \%$

- P2E0 : ransum dengan level protein $18 \%$ tanpa penambahan enzim $0,00 \%$

- P3E0 : ransum dengan level protein $20 \%$ tanpa penambahan enzim $0,00 \%$

- P1E1 : ransum dengan level protein $16 \%$ dan penambahan enzim $0,10 \%$

- P2E1 : ransum dengan level protein $18 \%$ dan penambahan enzim $0,10 \%$

- P3E1 : ransum dengan level protein $20 \%$ dan penambahan enzim $0,10 \%$

Data yang diperoleh dari hasil penelitian akan dianalisis keragaman (ANOVA) berdasarkan Rancangan Acak Lengkap (RAL) pola faktorial, Apabila terdapat pengaruh yang nyata maka dilanjutkan dengan Uji Jarak Berganda Duncan (Steel dan Torrie, 1993).

\section{HASIL DAN PEMBAHASAN}

\section{Konsumsi Ransum, Pertambahan Bobot Badan, dan Konversi Ransum}

Pengaruh perlakuan penggunaan level protein dalam ransum terhadap rataan konsumsi ransum, pertambahan bobot badan dan konversi ransum ayam kampung super dapat dilihat pada Tabel 4. Berdasarkan hasil analisis ragam menunjukan bahwa pengaruh penggunaan level protein dan enzim dalam ransum terhadap konsumsi ransum ayam kampung super menunjukkan interaksi yang tidak nyata $(\mathrm{P}>0,05)$. Begitu juga dengan secara faktor masing-masing, seperti pengaruh penggunaan faktor level protein dan faktor enzim juga tidak berpengaruh nyata $(P>0,05)$ terhadap konsumsi ransum.

Ternak mengkonsumsi ransum untuk memenuhi kebutuhan energi, jika energi yang tersedia dalam ransum tinggi maka ternak akan sedikit mengkonsumsi ransum tersebut. Hal ini menurut Suprijatna et al. (2006) perbedaan konsumsi ransum diduga sebagai akibat dari perbedaan kandungan nutrisi seperti kandungan protein dan kandungan energi metabolisme (EM) pada ransum tersebut. Kandungan protein dan energi metabolisme pakan yang berbeda dalam keadaan seimbang mengakibatkan tingkat konsumsi pakan yang cenderung sama (Negoro et al., 2013).

Konsumsi ransum ayam kampung super pada penelitian ini lebih rendah jika dibandingkan dengan hasil penelitian Kususiyah (2011) menyatakan bahwa konsumsi ransum sekitar 2699,20 g/ekor, pakan yang diberikan berupa konsentrat, jagung giling dan dedak halus (ransum oplosan) dengan kandungan protein 17\%. Faktor yang mempengaruhi konsumsi ransum yaitu faktor lingkungan dan ternak itu sendiri serta faktor pakan, hal ini sesuai hasil penelitian Koni et al (2019) menyatakan bahwa faktor pakan juga dipengaruhi oleh palatabilitas, aroma, warna, serta kasar dan lemak kasar.

Hasil analisis ragam menunjukan bahwa pengaruh penggunaan level protein dan enzim terhadap pertambahan bobot badan ayam kampung super (Tabel 4) menunjukkan interaksi yang tidak nyata $(\mathrm{P}>0,05)$. Namun masing-masing penggunaan level protein dan enzim dalam ransum berpengaruh sangat nyata $(\mathrm{P}<0,05)$ terhadap pertambahan bobot badan. Uji lanjut Duncan menunjukkan bahwa pertambahan bobot badan pada pemberian level protein $20 \%$ dan enzim $0,10 \%$ mampu meningkatkan pertambahan bobot badan dan memberi pengaruh yang nyata $(\mathrm{P}<0,05)$. 
Tabel 4. Rataan Konsumsi Ransum (g/ekor), Pertambahan Bobot Badan (g/ekor), da Konversi Ransum Selama 8 Minggu.

\begin{tabular}{|c|c|c|c|c|c|}
\hline \multirow[t]{2}{*}{ Peubah } & \multirow{2}{*}{$\begin{array}{c}\text { Enzim } \\
(\%)\end{array}$} & \multicolumn{3}{|c|}{ Level protein } & \multirow[b]{2}{*}{ Rataan } \\
\hline & & P1 & $\mathrm{P} 2$ & P3 & \\
\hline \multirow{3}{*}{$\begin{array}{l}\text { Konsumsi Ransum } \\
\text { (g/ekor) }\end{array}$} & E-0.00 & $2433,03 \pm 102,64$ & $2400,03 \pm 129,29$ & $2416,70 \pm 117,63$ & $2416,56 \pm 16,51$ \\
\hline & E-0.10 & $2439,91 \pm 316,00$ & $2418,24 \pm 106,29$ & $2347,94 \pm 92,41$ & $2402,03 \pm 48,08$ \\
\hline & Rataan & $2436,4 \pm 4,86$ & $2409,13 \pm 12,88$ & $2382,31 \pm 48,61$ & \\
\hline \multirow{3}{*}{$\begin{array}{l}\text { Pertambahan Bobot } \\
\text { Badan (g/ekor) }\end{array}$} & E-0.00 & $626,22 \pm 10,55$ & $647,51 \pm 11,59$ & $660,03 \pm 8,43$ & $644,58 \pm 17,09$ a \\
\hline & E- 0.10 & $650,13 \pm 11,33$ & $664,54 \pm 6,57$ & $685,82 \pm 7,96$ & $666,83 \pm 17,80 \mathrm{~b}$ \\
\hline & Rataan & $638,172 \pm 16,91^{a}$ & $656,025 \pm 12,04 b$ & $672,92 \pm 18,24 \mathrm{c}$ & \\
\hline \multirow[t]{3}{*}{ Konversi Ransum } & E-0.00 & $3,88 \pm 0,1$ & $3,71 \pm 0,22$ & $3,66 \pm 0,21$ & $3,75 \pm 0,12^{a}$ \\
\hline & E- 0.10 & $3,75 \pm 0,47$ & $3,64 \pm 0,15$ & $3,42 \pm 0,12$ & $3,60 \pm 0,17 \mathrm{~b}$ \\
\hline & Rataan & $3,82 \pm 0,09$ a & $3,68 \pm 0,05 \mathrm{ab}$ & $3,54 \pm 0,17$ b & \\
\hline
\end{tabular}

Keterangan: Superskrip berbeda pada baris dan kolom yang sama menunjukkan berbeda nyata $(\mathrm{P}<0,05)$. Faktor pertama, protein dengan level P1: 16\%, P2: 18\%, dan P3: 20\%, E0: ransum enzim 0,00\% E1: ransum 0,10\%. Faktor kedua, ezim dengan level: E0: 0,00\% dan E1: 0,10\%.

Menurut Trisiwi (2016) pertambahan bobot badan ayam kampung super dengan menggunakan pakan komersil starter broiler (BR-I) produksi PT Japfa Comfeed Indonesia dengan protein 21\% (P1), dan pakan campuran BR-I dengan penggantian 20 dan $40 \%$ tepung kulit roti dengan koreksi Asam Amino Esensial (P2 dan P3) memiliki pertambahan bobot badan yaitu 862,0 g/ekor (P1), 742,3 g/ekor (P2), 582,3 g/ekor (P3). Selain itu, menurut Mokodongan et al (2017) menyatakan bahwa rataan pertambahan berat badan ayam kampung (g/ekor) dengan penggunaan level protein yang berbeda yaitu $18 \%$ dan $20 \%$, pertambahan berat badan yang tertinggi yaitu dengan penggunaan level protein $20 \%$ sebesar 75,52 g/ekor, sedangkan pertambahan berat badan terendah yaitu dengan penggunaan level protein $16 \%$ sebesar $62,38 \mathrm{~g} / \mathrm{ekor}$.

Pada Tabel 4 menunjukkan bahwa pertambahan bobot badan tertinggi yaitu pada pemberian level protein $20 \%$ dengan menggunakan enzim $0,10 \%$ yaitu $685,82 \mathrm{~g} / \mathrm{ekor}$. Hal ini dikarenakan bahan pakan yang terkandung didalam ransum memiliki tingkat protein yang bagus dan ditambah pemberian enzim solagri 3 yang terdiri dari protease, selulase dan xylanase yang mampu memecah serat didalam ransum secara utuh dapat menghasilkan pertambahan bobot badan yang relatif tinggi hal ini hampir sama dengan hasil penelitian Noferdiman et al (2018) menyatakan bahwa penambahan enzim selulase sebanyak 0,10 \% dalam ransum mengakibatkan meningkatnya pertambahan bobot badan itik jika dibandingkan dengan tanpa enzim. Hal ini disebabkan oleh kerja enzim yang mampu merombak bahan pakan yang sulit dicerna oleh unggas menjadi lebih sederhana, dimana selulosa mampu meningkatkan kualitas ransum dengan mendegradasi komponen serat kasar terutama selulosa menjadi yang lebih sederhana.

Hasil analisis ragam menunjukkan bahwa perlakuan level protein dan enzim berbeda memberikan pengaruh terhadap konversi ransum $(\mathrm{P}<0,05)$, namun tidak memberikan interaksi yang tidak nyata $(\mathrm{P}>0,05)$ terhadap konversi ransum ayam kampung super (Tabel 4). Rataan konversi ransum cenderung menurun seiring dengan meningkatnya penggunaan level protein dan enzim, hal ini dikarenakan konversi tergantung pada konsumsi ransum dan pertambahan bobot badan, semakin rendah nilai konversi yang didapat maka tingkat efisiensi meningkat dan semakin ekonomis. Hal ini didukung oleh pendapat Kurniawan et al (2015) jika rasio konversi ransum yang didapat kecil, maka pertambahan bobot badan ayam memuaskan atau ayam makan dengan efisien dan diperkuat oleh Allama et al (2012) yang menyatakan bahwa nilai konversi ransum yang rendah menunjukkan bahwa efisiensi penggunaan ransum yang baik, karena semakin efisien ayam mengkonsumsi ransum untuk memproduksi daging. Konversi pakan dipengaruhi oleh konsumsi 
pakan, berat badan, kandungan nutrisi ransum, semakin besar angka konversi pakan, maka semakin kurang ekonomis penggunaan pakan tersebut (Fanani et al., 2017).

Konversi ransum yang didapat pada penelitian ini antara lain konversi yang terendah yaitu 3,42 dengan pemberian level protein 20\% dan enzim 0,10 \% sedangkan konversi ransum tertinggi yaitu 3,88 dengan pemberian level protein $16 \%$ dan tanpa menggunakan enzim Hal ini hampir sama dengan hasil penelitian Raras et al. (2017) konversi pakan ayam lokal persilangan umur 2 - 10 yang diberi bahan pakan sumber protein berbeda yaitu berkisar 3,67 - 4,33 dan didukung oleh Kususiyah (2011) yang menyatakan bahwa ayam kampung persilangan yang diberi pakan konsentrat jagung giling dan dedak halus (ransum oplosan) dengan kandungan protein 17\% memiliki konversi 3,95. Angka konversi pakan menunjukkan berapa banyak pakan yang digunakan untuk menaikan satu persatuan bobot badan ternak. Ransum yang baik adalah ransum yang dapat memenuhi kebutuhan nutrisi ayam dan lebih efisiensi dalam penggunaannya. Menurut Arabi (2015) perbedaan tingkat protein dalam pakan memiliki pengaruh yang nyata terhadap performans ayam, peningkatan kadar protein pakan, akan meningkatkan kinerja pertumbuhan.

\section{Bobot Potong, Bobot Karkas Mutlak dan Karkas Relative}

Pengaruh perlakuan level protein dan enzim terhadap rataan bobot potong, bobot karkas mutlak dan karkas relative ayam kampung super disajikan pada Tabel 5. Hasil analisis ragam menunjukkan bahwa pengaruh penggunaan level protein dan enzim berbeda dalam ransum tidak memberikan interaksi nyata $(\mathrm{P}>0,05)$ terhadap bobot potong, namun penggunaan masing-masing level protein dan enzim berbeda ini berpengaruh nyata $(\mathrm{P}<0,05)$ terhadap bobot potong ayam kampung super. Uji lanjut Duncan Menunjukkan bahwa peningkatan level protein dalam ransum hingga 20\% (P3) mampu meningkatkan bobot potong dan terdapat perbedaan nyata dengan penggunaan level protein $18 \%$ (P2) dan $16 \%$ (P1) serta penggunaan enzim $0,10 \%$ (E1) terdapat perbedaan nyata dengan penggunaan enzim $0,00 \%$ (E0).

Tabel 5. Rataan bobot potong (g/ekor), bobot karkas mutlak (g/ekor) dan karkas relative (\%) selama 8 minggu.

\begin{tabular}{|c|c|c|c|c|c|}
\hline \multirow[t]{2}{*}{ Peubah } & \multirow{2}{*}{$\begin{array}{c}\text { Enzim } \\
(\%)\end{array}$} & \multicolumn{3}{|c|}{ Level protein } & \multirow[b]{2}{*}{ Rataan } \\
\hline & & P1 & $\mathrm{P} 2$ & P3 & \\
\hline \multirow[t]{3}{*}{ Bobot Potong (g/ekor) } & E-0.00 & $663,21 \pm 7,85$ & $687,61 \pm 5,08$ & $699,05 \pm 9,64$ & $683,29 a \pm 18,31$ \\
\hline & E- 0.10 & $689,26 \pm 14,39$ & $702,36 \pm 7,41$ & $725,30 \pm 6,76$ & $705,64^{b} \pm 18,24$ \\
\hline & Rataan & $676,23 \mathrm{a} \pm 18,42$ & $694,98^{\mathrm{b}} \pm 10,43$ & $712,17 \_ \pm 18,56$ & \\
\hline \multirow[t]{3}{*}{ Karkas Mutlak (g/ekor) } & E-0.00 & $439,67 \pm 10,90$ & $459,95 \pm 9,29$ & $472,62 \pm 1,96$ & $457,41^{a} \pm 16,62$ \\
\hline & E- 0.10 & $464,89 \pm 9,17$ & $480,73 \pm 6,13$ & $499,94 \pm 5,72$ & $481,85^{b} \pm 11,10$ \\
\hline & Rataan & $452,28 \mathrm{a} \pm 17,83$ & $470,34 \mathrm{~b} \pm 14,69$ & $486,28 \mathrm{c} \pm 9,66$ & \\
\hline \multirow[t]{3}{*}{ Karkas Relative (\%) } & E- 0.00 & $66,30 \pm 0,90$ & $66,89 \pm 0,95$ & $67,66 \pm 1,21$ & $66,95^{\mathrm{a}} \pm 0,68$ \\
\hline & E- 0.10 & $67,47 \pm 1,64$ & $68,45 \pm 0,33$ & $68,94 \pm 0,85$ & $68,29 \mathrm{~b} \pm 0,61$ \\
\hline & Rataan & $66,89^{a} \pm 0,83$ & $67,67^{a b} \pm 1,26$ & $68,30^{\mathrm{b}} \pm 0,45$ & \\
\hline
\end{tabular}

Keterangan: Superskrip berbeda pada baris dan kolom yang sama menunjukkan berbeda nyata $(\mathrm{P}<0,05)$. Faktor pertama, protein dengan level P1: 16\%, P2: 18\%, dan P3: 20\%, Faktor kedua, enzim dengan level: E0: 0,00\% dan E1: 0,10\%.

Rataan bobot potong ayam kampung super yang diberi perlakuan penggunaan level protein dan enzim cenderung meningkat, seiring dengan meningkatnya penggunaan level protein dan enzim dalam ransum. Hal ini disebabkan karena semakin tinggi penggunaan protein maka protein akan diolah menjadi hasil yang lebih efisien sesuai kebutuhan sehingga ternak mampu menghasilkan bobot potong yang lebih tinggi. Protein merupakan salah satu nutrisi yang dapat mempengaruhi pertumbuhan dan pembentukan jaringan karkas, sehingga protein ransum dapat mempengaruhi tingkat bobot badan ternak (Samsudin et al., 2016). 
Bobot potong tertinggi pada perlakuan penggunaan level protein 20\% (P3) yaitu 712,17 g/ekor dan penggunaan enzim 0,10\% (E1) yaitu 705,64 g/ekor sedangkan terendah pada perlakuan penggunaan level protein 16\% (P1) yaitu 676,23 g/ekor dan penggunaan enzim 0,00\% (P0) yaitu $683,29 \mathrm{~g} /$ ekor. Hasil ini lebih besar dari penelitian Suartiningsih et al. (2017) menyatakan bobot potong ayam kampung berumur 10 minggu dengan ransum penggunaan tepung kulit buah naga terfermentasi berkisar antara 464,88 - 468,36 g/ekor. Namun lebih rendah dari hasil penelitian Sigaha et al. (2019) menyatakan rataan bobot potong ayam kampung super yaitu 850,75 g/ekor.

Penggunaan enzim solagri 3 dalam ransum cenderung menghasilkan rataan bobot potong yang lebih tinggi dibandingkan dengan tanpa enzim. hal ini karena enzim bekerja membantu proses penyerapan nutrisi di saluran pencernaan sehingga mampu meningkatkan bobot potong. Penambahan multi enzim mampu memperbaiki efisiensi penggunaan ransum dan memudahkan proses pencernaan dalam tubuh ternak sehingga mampu meningkatkan produksi (Sinaga et al., 2019).

Hasil analisis ragam menunjukan bahwa pengaruh penggunaan level protein dan enzim dalam ransum terhadap bobot karkas menunjukan interaksi yang tidak nyata $(\mathrm{P}>0,05)$, namun dilihat dari masing- masing perlakuan penggunaan level protein dan enzim dalam ransum berpengaruh nyata $(\mathrm{P}<0.05)$ terhadap bobot karkas ayam kampung super. Rataan bobot karkas dengan penggunaan level protein dan enzim dalam ransum cenderung meningkat, seiring dengan meningkatnya penggunaan level protein dan enzim dalam ransum. Uji lanjut duncan menunjukkan bahwa peningkatan level protein dalam ransum hingga 20\% (P3) mampu meningkatkan bobot karkas yang berarti terdapat perbedaan yang nyata terhadap level protein 18\% (P2) dan 16\% (P1). Pada enzim menunjukan bahwa penggunaan enzim $0,10 \%$ (E1) terdapat perbedaan yang nyata dengan perlakuan tanpa penggunaan enzim $0,00 \%$ (E0).

Bobot karkas tertinggi pada perlakuan penggunaan level protein 20\% (P3) yaitu 486,28g/ekor dan penggunaan enzim $0,10 \%$ (E1) yaitu $481,85 \mathrm{~g}$ kemudian terendah pada perlakuan penggunaan level protein 16\% (P1) yaitu 452,28g/ekor dan penggunaan enzim 0,00\% (E0) yaitu 457,41g/ekor. Hal ini sama dengan hasil penelitian Sukmawati et al. (2015) menyatakan rataan bobot karkas ayam kampung adalah 468,75g/ekor dan penelitian Selviana et al. (2019) menyatakan rataan bobot karkas ayam kampung super dengan penambahan kulit singkong dan bakteri asam laktat sebagai aditif pakan yaitu 427,17-480,50 g/ekor. Hal ini lebih rendah dari hasil penelitian menunjukkan bahwa rata-rata bobot karkas ayam buras super umur 12 minggu dengan perlakuan frekuensi dan periode pemberian pakan berkisar 730,5 - 851,25 g/ekor (Darmawan et al., 2017).

Rataan bobot karkas sangat berkaitan bobot potong, semakin tinggi bobot potong maka semakin tinggi bobot karkas nya. Hal ini sesuai dengan pendapat Akmal (2008) bahwa bobot potong erat hubunganya dengan bobot karkas. Beragamnya penggunaan level protein dalam ransum menghasilkan bobot karkas yang beragam pula hal ini disebabkan karena dalam proses pencernaan protein diubah menjadi asam amino sehingga terbentuknya tulang dan daging. Hal ini sesuai dengan pendapatnya Qotimah et al (2014) bahwa protein ransum dapat mempengaruhi bobot karkas. Asam amino merupakan bahan utama dalam proses pembentukan daging (Adnyana et al., 2014).

Penggunaan enzim solagri 3 kedalam ransum dapat meningkatkan bobot karkas, peningkatan ini membuktikan bahwa enzim mampu meningkatkan kecernaan zat-zat makanan terutama protein dan energi sehingga ketersediaan dan penyerapan protein dan energi dalam tubuh dapat digunakan untuk pembentukan karkas. Penambahan multi enzim pencernaan dan probiotik mampu meningkatkan kualitas karkas ayam lokal pedaging unggul (Ridhana, 2014).

Hasil analisis ragam menunjukan bahwa pengaruh penggunaan level protein dan enzim dalam ransum terhadap bobot karkas relatif menunjukan interaksi yang tidak nyata $(P>0,05)$, namun dilihat dari masing-masing penggunaan level protein dan enzim dalam ransum menunjukan 
pengaruh yang yang nyata $(\mathrm{P}<0,05)$ terhadap bobot karkas relatif ayam kampung super. Uji lanjut duncan menunjukkan bahwa peningkatan level protein dalam ransum hingga 20\% (P3) terdapat perbedaan yang nyata terhadap penggunaan level protein 16\% (P1) tetapi tidak berbeda terhadap penggunaan protein di level $18 \%$ (P3). Pada enzim penggunaan enzim 0,10\% (E1) terdapat perbedaan yang nyata terhadap penggunaan enzim $0,00 \%$ (E0).

Persentase karkas tertinggi yaitu pada perlakuan penggunaan level protein 20\% (P3) yaitu $68,30 \%$ dan penggunaan enzim 0,10\% (E1) yaitu 68,29\% kemudian terendah pada perlakuan penggunaan level protein $16 \%$ (P1) yaitu $66,89 \%$ dan penggunaan enzim $0,00 \%$ (E0) yaitu 66,95\%. Hal ini sama dengan hasil penelitian Tahalele et al (2018) melaporkan bahwa bobot karkas relatif ayam kampung super mendapatkan hasil $68,40 \%$. Hasil tersebut juga lebih tinggi dari penelitian Muryanto et al (2002) rata-rata bobot karkas relatif ayam kampung dan ayam hasil persilangan antara ayam kampung jantan dengan ayam ras petelur betina strain lohman atau ayam kampung super umur 12 minggu dengan pemberian ransum komersil protein 21\% dan 14\% adalah 60,05 \% dan 58,87 \%. Rataan persentase karkas menunjukan bahwa protein berperan penting dalam pembentukan karkas dalam proses pencernaan ransum sehingga mampu menghasilkan bobot potong yang mempengaruhi bobot karkas mutlak sehingga menghasilkan bobot karkas relatif yang tinggi. Energi dan protein merupakan nutrient utama yang mempengaruhi produksi karkas ayam (Adnyana et al., 2014).

\section{KESIMPULAN}

Berdasarkan dari hasil penelitian dapat disimpulkan bahwa Penggunaan level protein $20 \%$ dalam ransum dapat meningkatkan performa ayam kampung super. Penggunaan enzim 0,10\% dalam ransum dapat meningkatkan performa ayam kampung super.

\section{UCAPAN TERIMA KASIH}

Ucapan terima kasih disampaikan pada Rektor Universitas Jambi, Direktur Pascasarjana Universitas Jambi dan Ketua Lembaga Penelitian dan Pengabdian pada Masyarakat Universitas Jambi yang memberikan dukungan dalam penelitian atau penulisan makalah, baik sebagai penyediaan dana PNBP Pascasarjana Universitas Jambi, fasilitas penelitian dan pengurusan administrasi pelaksanaan penelitian.

\section{DAFTAR PUSTAKA}

Adnyana, I.G.S., G.A.M.K. Dewi \& M. Wirapartha. (2014). Pengaruh imbangan energi dan protein ransum terhadap karkas ayam kampung betina umur 30 minggu. Peternak. Tropika, 2(1), 415424.

Akmal, A., (2008). Pengaruh pemberian daun sengon (albizzia falcataria) hasil rendaman dengan larutan ca(oh)2 terhadap bobot karkas dan bobot organ pencernaan ayam pedaging. Jurnal Ilmu-ilmu Peternakan, 11(1), 100-107. https://doi.org/10.22437/jiiip.v11i4.739

Allama, H., O. Sofyan, E. Widodo, \& H.S. Prayogi. (2012). Pengaruh penggunaan tepung ulat kandang (Alphitobius diaperinus) dalam pakan terhadap penampilan produksi ayam pedaging. Jurnal Ilmu-Ilmu Peternakan, 22(1), 1-8.

Arabi, S.A.M., (2015). The effects of different protein and energy levels on broilers performance under hot climatic conditions. International Jurnal Innovation Agriculture Biology, 3(1), 19-28.

Darmawan, I., E. Suprijatna \& U. Atmomarsono. (2017). Pengaruh frekuensi dan periode pemberian pakan terhadap produksi karkas ayam buras super. Jurnal Peternakan Indonesia, 19(1), 10-15. 
Fanani, A.F., N.Suthama \& B. Sukamto. (2017). Retensi nitrogen dan konversi pakan ayam lokal persilangan yang diberi ekstrak umbi dahlia (dahlia variabilis) sebagai Sumber Inulin. Sains Peternakan, 13(1), 69.

Fitasari, E., Reo, K., \& Niswi, N. (2016). Penggunaan kadar protein berbeda pada ayam kampung terhadap penampilan produksi dan kecernaan protein. Jurnal Ilmu-IImu Peternakan, 26(2), 7383.

Fitasari, E., K. Reo \& N. Niswi. (2017). Penggunaan kadar protein berbeda pada ayam kampung terhadap penampilan produksi dan kecernaan protein. Jurnal Ilmu-Ilmu Peternakan, 26(1), 73-83.

Koni, T.N.I., T.A.Y. Foenay \& Asrul. (2019). The nutrient value of banana peel fermented by tape yeast as poultry feedstuff. Jurnal Ilmu-Ilmu Peternakan, 29(1), 234-240. https://doi.org/10.21776/ub.jiip.2019.029.03.05

Kurniawan, A. S., Oktovianus R, Nahak T.B., \& Agustinus A D. (2015). Perbandingan Penggunaan Dua Jenis Ransum Terhadap Pertambahan Bobot Badan Harian (PBBH), Konsumsi Ransum dan Konversi Ransum Ayam Broiler. Journal of Animal Science, 1(1), 1-3.

Kususiyah, (2011). Performans pertumbuhan ayam peraskok sebagai ayam potong belah empat serta nilai income over feed and chick cost. Jurnal Sains Peternakan Indonesia, 6(1), 83-87.

Mokodongan, A.R., F. Nangoy., J.R. Leke \& Z. Poli. (2017). Penampilan pertumbuhan ayam bangkok starter yang diberi pakan dengan level protein berbeda. Zootechnology, 37(1), 426.

Muryanto, H.P., R. Herman \& H. Setijanto. (2002). Evaluasi karkas hasil persilangan antara ayam kampung jantan dengan ayam ras peterlur betina. Journal of Animal Production, 4(1), 71-76.

Nawawi, T., \& Nurrohmah, (2015). Pakan Ayam Kampung. Jakarta: Penebar Swadaya.

Negoro, A.S.P., Achmanu, \& Muharlien, (2013). Pengaruh Penggunaan Tepung Kemangi dalam Pakan Terhadap Penampilan Produksi Ayam Pedaging. 3(1), 1-6.

Noferdiman, Lisna, \& Y. Damayanti. (2018). Penggunaan tepung azolla microphilla dan enzim selulase dalam ransum terhadappenampilan produksidan nilai ekonomis itik lokal kerinci jantan. Pastura Jurnal Tropical Forage Science, 8(1), 20-25.

NRC, (1994). Nutrient Requirements of Poultry, 9th rev. ed. Washington, DC: Natl. Acad. Pressn, Poultry Science. https://doi.org/10.3382/ps.0740224

Qotimah, S., S. Urip \& S. Edi. (2014). Pengaruh level protein dan suplementasi ekstrak daun katuk (sauropus androgynus) terhadap kualitas karkas broiler. Jurnal sain Peternakan Indonesia, 9(1), 130-136.

Raras, A., R. Muryani \& W. Sarengat. (2017). Pengaruh pemberian tepung azolla fermentasi (Azolla microphylla) terhadap performa ayam kampung persilangan. Jurnal Peternakan Indonesia, 19(1), 30. https://doi.org/10.25077/jpi.19.1.30-36.2017

Ridhana, F., (2014). Peningkatan Kualitas Karkas Ayam Lokal Pedaging Unggul (ALPU) Melalui Fermentasi dengan Penambahan Multi Enzim Pencernaan dan Probiotik. Thesis. Prog. Magister kesehatan masyarakat veteriner. Unsyiah.

Samsudin, M dan E. Suprijatna \& Isroli. (2016). Performa karkas ayam kampung periode starter akibat pemberian probiotik pada protein ransum yang berbeda. Jurnal iImu-ilmu Pertanian, $39-46$.

Selviana, N., E. Suprijatna \& L. Mahfudz. (2019). Pengaruh penambahan kulit singkong dan bakteri asam laktat sebagai aditif pakan terhadap produksi karkas ayam kampung super. Indonesian Journal of Animal. Science 3(1), 145-152.

Sigaha, F., E.J. Saleh \& S. Zainudin. (2019). Evaluasi persentase karkas ayam kampung super dengan pemberian jermai jagung fermentasi. Jambura Journal of Animal Science. 2(1), 1-7. https://doi.org/10.35900/jjas.v2i1.3004

Sinaga, R., E. Suprijatna \& S. Kismiati. (2019). Pengaruh pemberian tepung kiambang (salvinia molesta) dengan aditif multienzim dalam ransum terhadap performans itik tegal. Jurnal IImuilmu Pertanian. 15(1), 121-131. https://doi.org/10.1017/CB09781107415324.004

Steel, R. G., \& Torrie, J. H. (1993). Prinsip dan prosedur statistika. Jakarta: Gramedia Pustaka Utama.

Suartiningsih, Ni Pande Made., Dewi, Gusti A. M. kristina., I.M. Nuriyasa \& W. Wijana. (2017). Produksi karkas ayam kampung yang di beri ransum kulit buah naga (hylocereus polyrhizus) terfermentasi. Prosiding Seminar Nasional VI HITPI "Peran Strategis Tumbuhan Pakan dalam 
Mendukung UPSUS SIWAB untuk Mewujudkan Ketahanan Pangan" Jambi, 23 - 24 November 2017

Sukmawati, Sampurna. I ., M. Wirapartha., N. Siti \& I. Ardika. (2015). Penampilan dan komposisi fisik karkas ayam kampung yang diberi jus daun pepaya terfermentasi dalam ransum komersial. Majalah Ilmu Peternakan. 18(1), 39-43.

Suprijatna, E., L.D. Mahfudz \& H.Saputra (2006). Effect of dietary protein in growing period on efficiency of dietary protein utilisation and performance at onset of lay of ' arab ' chicken. Jurnal Indonesia Tropical Animal. Agriculture, 31(1), 111-116.

Tahalele, Y., M.E.R. Montong., F.J. Nangoy \& C.L.K. Sarajar. (2018). Pengaruh penambahan ramuan herbal pada air minum terhadap persentase karkas, persentase lemak abdomen dan persentase hati pada ayam kampung super. Journal of Zootechnology, 38(1), 160. https://doi.org/10.35792/zot.38.1.2018.18630

Trisiwi, H.F., (2016). pengaruh levelprotein pakan yang berbeda pada masa starter terhadap penampilan ayam kampung super. Jurnal Ilmu Peternakan terpadu, 4(1), 256-262.।

Udjianto, A., (2018). Beternak Ayam Kampung Paling Unggul, Pedaging dan Petelur KUB. Jakarta: Penebar Swadaya. 